\title{
You Study Like a Girl: Experiences of Female Sport Management Students
}

\author{
Erin Morris, Ryan Vooris, and Tara Q. Mahoney \\ State University of New York, Cortland
}

\begin{abstract}
Female students are underrepresented within university sport management programs. Because of the concept of the "chilly climate," the underrepresentation may impact their experiences as students and their opportunities inside and outside of the classroom. The purpose of this study was to gain a better understanding of female students' experiences within this maledominated major. Three qualitative focus groups with female sport management students were conducted. The results found the female students had strategies to overcome barriers, a firm understanding of the reality of the gender dynamic within sport management, and an awareness of the importance of networking to succeed in the major. These findings may help sport management programs better support their female students through initiatives like women-in-sport-management clubs.
\end{abstract}

Keywords: chilly climate, female students, gender, higher education, women in sport

It is a well-documented reality that female students are underrepresented within the undergraduate major of sport management (Chen, Adams-Blair, \& Miller, 2013; Hancock \& Greenwell, 2013; Harris, Grappendorf, Aicher, \& Veraldo, 2015; Moore, 2008; Moore \& Huberty, 2014). Recent data suggest that women represent less than $25 \%$ of student enrollment in sport management programs (Chen et al., 2013). Barnhill, Czekanski, and Pfleegor (2018) found that $36 \%$ of the respondents to their survey of 12 introduction to sport management courses were women. This low rate of women in sport management persists despite the fact that the representation of female students in higher education has increased dramatically since the 1970s (Marcus, 2017). According to the most recent data from the U.S. Department of Education, 56\% of college and university students are women (National Center for Education Statistics, 2017). Although women attend college more frequently than men, this gender distribution is not seen in undergraduate business programs such as sport management. Female students are about $40 \%$ less likely than male students to choose a business-related college major (Ball, 2012). Often, women are discouraged from pursuing business-related majors while in college (Levsen, Goetell, Chong, \& Farris, 2001).

The underrepresentation of women also occurs in the sports industry. Yiamouyiannis and Osborne (2012) found that women were lacking in leadership positions at all levels of college athletics, including coaching, administration, and governance. For instance, at the college level, only $22.3 \%$ of athletic directors are women (Acosta \& Carpenter, 2014). The representation issue also extends to the professional sports world. While $46.8 \%$ of the U.S. workforce is female (U.S. Department of Labor, 2017), women only hold $27.7 \%$ of administration positions among Major League Baseball teams and $31.8 \%$ of positions at Major League Baseball's home office (Lapchick, 2018a). In addition, women hold 39.6\% of National Basketball Association front office positions, $31.6 \%$ in

The authors are with Sport Management Dept., State University of New York, Cortland, Cortland, NY. Morris (erin.morris02@cortland.edu) is corresponding author.
National Basketball Association league administration positions (Lapchick, 2018b), 20.6\% of team administration positions in the National Football League, and $35.4 \%$ of the National Football League office positions (Lapchick, 2017).

Jones, Brooks, and Mak (2008) identified the underrepresentation of female students in the major of sport management as one of the critical issues facing the field. Other scholars have identified the need to understand why women choose sport management as a major and what factors lead them to potentially drop out of the major (Moore, 2008). As Harris et al. (2015) and Chen et al. (2013) pointed out, it is vital for academics to hear directly from these students because it helps academics understand student perceptions of their roles within the major and the industry. By listening to the experiences of female sport management majors, faculty members and administrators can also learn how to better recruit and mentor female students (Chen et al., 2013). Furthermore, Taylor, Johnson, Hardin, and Dzikus (2018) indicated the need for more qualitative research to explore how female students were dealing with sexism in the classroom. Therefore, the purpose of this study was to gain a better understanding of female students' experiences within the sport management major by talking directly with female students in controlled focus groups.

Given the underrepresentation of women in sport management programs, it is likely that female students experience the major in substantially different ways than male students, who make up the majority of the student body (Harding, 1987; Hartsock, 1983). Women will likely experience the labor force and other aspects of life differently and possibly in "othered" ways from men, particularly when the environment is highly gendered (Hartsock, 1983). This study utilized the concept of "chilly climate" to focus on the voices of women in a male-dominated space (Hall \& Sandler, 1982). Given that only a minority of students in sport management are female, it is important to understand the lived experiences of those students.

\section{Review of Literature}

\section{Women in the Sport Management Major}

The low enrollment of women in sport management programs is well documented. Nearly a quarter-century ago, Hums (1994) 
reported that women represented only about one fourth of students electing to major in sport management. Jones et al. (2008) indicated that more than $80 \%$ of sport management programs had a female population below $40 \%$. They also found that $40 \%$ of sport management programs had about one female student for every four male students. Chen et al. (2013) showed that the enrollment of female students in the sport management major was less than $25 \%$ and wrote of the need to recruit and mentor more female students. These three studies present 25 years of documentation showing that little has changed when it comes to women's enrollment in the major of sport management. As stated previously, this trend does not reflect the broader trend of more women pursuing secondary degrees (National Center for Education Statistics, 2017). Various scholars have attempted to understand this issue within the sport management literature.

Research on female students and their perceptions of the sport management major have produced numerous findings relevant to this study. Female students in the major tend to state they were unaware of the major before joining college (Harris, Grappendorf, Veraldo, \& Aicher, 2014). They tend to first become interested in the major because they have an interest in sport or play a sport (Chen et al., 2013; Hancock \& Greenwell, 2013). Female students are often fully aware that both the sport management major and the sport industry is male dominated (Harris et al., 2014, 2015). However, Taylor et al. (2018) established, using the Ambivalent Sexism Inventory, that many students believed there are high levels of hostile and benevolent sexism within the major. Female students reported the need to develop coping methods to manage their minority status in the major, including the need to take leadership positions when engaged in group work, finding ways to enhance their sports knowledge, and working closely with faculty members who serve as mentors (Harris et al., 2014). Leberman and Shaw (2015) found that female students identified specific skills they learned as undergraduates that helped them in their careers. These included independent learning, time management, interpersonal communication, and devising and executing plans of actions. Chen et al. (2013) also identified communication skills as one of the most valued quantities developed by undergraduate sport management students.

Female sport management students also have different reasons for choosing the major. Hancock and Greenwell (2013) found that female students were more concerned with program quality and convenience when choosing the sport management major. On the other hand, male students were more interested in the potential for a high-paying salary in their careers. Hancock and Greenwell also stated that the lack of female representation in the classroom may dissuade other women from choosing sport management as a major. Students also express frustration at explaining the major of sport management and why they chose it (Harris et al., 2014). This frustration can sometimes be compounded by parents who raise objections when their daughters choose male-dominated careers (Harris et al., 2014; Whitmarsh, Brown, Cooper, HawkinsRodgers, \& Wentworth, 2007).

There are other important considerations to mention when discussing the experiences of female students in male-dominated majors like sport management. Gender diversity among faculty is important because it allows female students to have role models and mentors (Moore \& Huberty, 2014). In addition, female athletes and women's sports continue to receive less media coverage than their male counterparts, a marginalization that may cause some students to replicate those attitudes in the classroom (Taylor, Smith, Rode, \& Hardin, 2017). Finally, previous research lends credence to the concept that same-gender faculty in male- or female-dominated disciplines may benefit students when it comes to their interest in the subject (Bettinger \& Long, 2005).

Harris et al. (2015) examined the perceptions of female sport management students for their future careers. Their research found that female students felt they had to deal with negative gender stereotypes, such as the belief that they did not know as much about sports as their male classmates. Students felt that "being female equate[d] to a lack of knowledge about sport" (p. 16). Furthermore, female students felt they had to work harder than male students to overcome gender discrimination. Sauder, Mudrick, and DeLuca (2018) reaffirmed these findings in their study of perceived barriers and supports of female undergraduate sport management students. They found that the students felt a sense of otherness and were perceived as less credible. Harris et al. (2015) commented that it is concerning that this perception is so strong because it may cause students to avoid the major or a career in sport. Female students also identified difficulty networking and the need to balance work and family as potential obstacles for them to overcome in their careers and had a high awareness of the gender discrepancy in their classes and in the sport industry (Harris et al., 2015).

\section{Chilly Climate}

The concept of the chilly climate for women in education was first developed by Hall and Sandler (1982). In short, the concept is centered on the idea that there are subtle, but important differences in how women are treated in the classroom. These subtle differences include such things as male students being called on more frequently than female students, faculty making eye contact more often with male students, and male students receiving more praise and assistance than female students (Hall \& Sandler, 1982). In addition, the chilly climate can manifest itself through the types of questions students are asked. Male students are more likely to be asked open-ended questions, while women often get asked straightforward yes-or-no questions (Sandler, 2005).

Elements of this chilly climate behavior can also be produced by male students when they interact with female students. For example, male students may seek to complete work for women, thus eliminating their opportunity for personal growth, or male students may express hesitation at a woman's ability to complete an important group task (Sandler, 2005). This male-dominated learning environment is more pronounced in certain male-dominated majors (Harris et al., 2014). The chilly climate can impact female students' self-confidence and cause them to change their major (Sandler, 2005). Sometimes a chilly climate can even come from parents if they discourage their children from pursuing majors in nontraditional fields (Harris et al., 2014). Furthermore, within the major of sport management, a patriarchal climate can be created, which in turn, impedes inclusion. Moore and Huberty (2014) wrote of this:

The post-feministic climate could be difficult on students who have intent to cultivate impersonal skills for public relations or other pertinent careers but who had those ambitions subjugated by a proclivity within the discipline to inculcate masculine principles such as conventions on organizational effectiveness and efficiencies. Students may find themselves in an uncovetous predicament of either conforming to the climate and its value system or isolating themselves from full climatic navigation. (p. 22)

In summation, the chilly climate at many postsecondary institutions can impede the cognitive learning process of women (Pascarella et al., 1997). The manifestation of this climate often occurs in many 
subtle ways (Boyer, 1987), including everyday behaviors and institutional practices (Hall \& Sandler, 1982). Pascarella et al. (1997) suggested it is important for faculty and administrators to understand the climate for women at each campus. Constant and vigilant awareness of these experiences can serve to benefit women, particularly those in male-dominated fields (Harris et al., 2014; Whitmarsh et al., 2007).

\section{Statement of the Problem}

The purpose of this study was to gain an understanding of the experiences of female students majoring in sport management. The concept of the chilly climate suggests that subtle, institutional discrimination may be harming their learning opportunities and impeding their acceptance of the major as a feasible career path. Many sport management researchers wrote of the importance of talking to female students to see if they perceive such a climate (Chen et al., 2013; Harris et al., 2014; Pascarella et al., 1997). Examining the female students' experiences allows a greater understanding of what issues they face in the classroom, how to better support and mentor female students, and how to recruit more female students to the major. Following the call of Taylor et al. (2018) for more qualitative work on the experience of female sport management students in the classroom, this study utilized focus groups of female students enrolled in a sport management program to gain a better understanding of their lived experience in the major.

\section{Methods}

Krueger and Casey (2000) defined focus groups as "carefully planned series of discussion[s] designed to obtain perceptions on a defined area of interest in a permissive non-threatening environment" (p. 5). Multiple focus groups of four to seven participants help to ensure that all participants have a greater opportunity to speak and meaningfully interact with one another (Krueger \& Casey, 2000; Munday, 2014). As such, this study included three focus group discussions, with a total of 15 participants. Data saturation was reached after the third focus group, when new themes were not emerging from the focus groups (Glaser \& Strauss, 1967).

\section{Participants and Procedure}

Approval from the institutional review board was granted for this study. A convenience sample of female students majoring in sport management from a midsize Division III institution in the Northeast were asked to participate in the focus group. During the 2017-2018 academic year, women represented $20.1 \%$ of students within the sport management major at this school, a number in line with recent research on the broader representation of women in the major (Chen et al., 2013). An e-mail was sent to all female students in the sport management major, asking if they would be willing to participate. The students interested in participating were asked to e-mail the first author. Nineteen students responded to the e-mail. Of those 19 students, 15 were able to make one of the three scheduled focus groups.

Those 15 students were grouped into three focus groups, based on their availability. The first two focus groups consisted of six participants each, and the third focus group consisted of three participants. Two groups were conducted in person, while the third was conducted using the Google Hangout video chat so that online students and students who were off campus due to internships could participate. Thirteen participants were in the undergraduate program, and two were in the graduate program. In order to encourage participants to share personal experiences and views, pseudonyms were assigned; the researchers requested that the conversations be kept confidential, and informed consent forms were signed. As such, this sample represents approximately $15 \%$ of the female sport management students and 3\% of all sport management students. Due to the nature of the topic, focusing on women's experiences, the researchers found it important to create a women-specific space for the focus groups. In order to do so, the female authors of this study served as the interviewers, and the focus groups took place in a meeting room outside of the sport management department.

A semistructured interview guide was utilized to elicit the participants' experiences as sport management majors. The interview guide covered topics derived from previous research on the experiences of female students, including classroom interactions, how they are treated by their peers, barriers to success in sport management, and tools that help them succeed in sport management (see Table 1).

The researchers were regularly in contact with these students before and after the focus groups. This allowed the researchers to have a rapport with the students going into the focus groups. However, this could also lead to issues of bias, where students may be hesitant about sharing concerns about the department. At the beginning of the focus group, the researchers informed the students that they wanted to hear critiques about the department. The researchers' desire to improve the department, based off of student feedback, was frequently reiterated during the discussion.

\section{Data Analysis}

The focus groups ranged in length from 31 to $52 \mathrm{~min}$ and were digitally recorded with the consent of the participants. The recordings were transcribed verbatim. Pseudonyms were assigned

\section{Table 1 Focus-Group Questions}

Topic 1: Classroom experience

Topic 2: Barriers and strategies

Topic 3: Support
How many other women do you tend to be in class with in sport management classes?

Does this impact how you act/interact in class?

Do you feel like you are treated differently by your peers based on your gender?

What barriers are there to your success as a student in sport management?

What are some strategies you utilize to succeed in this field?

What supports exist in the department that help you succeed?

Are there any additional supports that the department could provide that would make it easier to succeed as a woman in sport management?

If you had a magic wand and could change anything in the department to make it better for female students, what would it be? 
throughout the transcripts. As the two researchers conducting the interviews were women who both teach in the male-dominated field of sport management, the researchers utilized several tools to ensure that their positionality did not bias the interpretation of results. After the conclusion of each focus group, the interviewers debriefed with the third researcher, who is male, about what was heard in the interview. This allowed them to get an outside perspective on the immediate discussion of the findings. In addition, memos were made regarding common themes and intriguing ideas that were discussed during the sessions.

Independently, all of the researchers used inductive coding techniques to individually identify emergent themes from the data. Inductive data analysis is useful for exploratory research where there is limited previous research or literature around a subject (Creswell \& Creswell, 2018). In addition, inductive data analysis is used "to establish clear links between the evaluation or research objectives and the summary findings... and to develop a model or theory about the underlying structure of experiences or process that are evident in the text data" (Thomas, 2006, p. 238). Each author individually coded the transcripts. Subsequently, the authors discussed the similarities and differences in their codes until they reached an agreement on the main themes and subthemes (Hambrick, Simmons, \& Mahoney, 2013; Patton, 2002). The authors agreed on three main themes, (a) overcoming barriers, (b) understanding reality, and (c) networking, with two to four subthemes each. Table 2 displays these themes and subthemes with a brief summary for each. Representative quotes were then selected for the themes and subthemes and are reproduced without any changes to spelling, grammar, and sentence structure, except where noted.

\section{Results and Discussion}

The overarching themes emergent from the data regarding the experiences of female sport management students include (a) overcoming barriers, (b) understanding reality, and (c) networking. The results were documented and discussed in the following subsections.

\section{Overcoming Barriers}

The participants consistently talked about how they overcame the barriers they experienced as female students. While the participants spent minimal time talking about barriers themselves, often noting that they did not perceive many barriers to their success in sport management, they frequently discussed several mechanisms they believed would help them succeed. These mechanisms constituted four subthemes: interacting with others, joining the conversation, using minority status as an advantage, and going above and beyond.

Interacting With Others. Many of the students stated they were intimidated by the number of men in major-specific classes and were hesitant to speak up. However, as the participants got to know their classmates, they found it easier to participate in class and felt more comfortable. Claire discussed this: "I think also, for me, it's I see the same faces in a few of my classes, so that makes me more comfortable too, knowing that I already kind of have a connection with them." Mary echoed this when asked what advice she would give to future female students: "Don't put your head down and be intimidated, because it gets better. Honestly, it gets better every year. Between the friends you make, like all the guys you're friends with."

The female students appeared to gain confidence in themselves and their abilities as they got more comfortable with their peers. Through this interaction, the participants were able to minimize the impact of being a minority in the classroom. While the literature on chilly climate discussed that the lack of women in a major can impact female students' self-confidence and cause them to switch majors (Sandler, 2005), the participants in this study gained confidence through getting to know their male classmates better. A limitation of this finding was that the focus group did not include women who had transferred out of the major; the chilly climate could be the reason for their departure.

Another aspect of interacting with others involved the participants creating support systems for themselves, which helped them succeed in their gendered reality. This was primarily done by making friends with the other female students, as well as learning which male students had similar work ethics and made good group partners. The students in this study recognized that every group had distinct dynamics; however, those dynamics were often gendered, where they were often expected to carry a heavier workload than their male peers. Several of the participants discussed how the women in the major automatically become friends with each other since there were so few of them and it gave them a friend in class. Mary said, "Walking into class and seeing somebody, even if it's a

\section{Table 2 Themes and Subthemes}

\begin{tabular}{|c|c|c|}
\hline Theme & Subthemes & Definition \\
\hline \multirow[t]{4}{*}{ Overcoming barriers } & Interacting with others & Participants learning to be comfortable when interacting with classmates. \\
\hline & Joining the conversation & $\begin{array}{l}\text { Coping mechanisms related to informal conversations with classmates around } \\
\text { sport current events. }\end{array}$ \\
\hline & Using minority status as an advantage & $\begin{array}{l}\text { Participants found advantages to being in the minority, including faculty being } \\
\text { more likely to know their names. }\end{array}$ \\
\hline & Going above and beyond & $\begin{array}{l}\text { Participants attempted to mitigate being in the minority by trying to set themselves } \\
\text { apart academically. }\end{array}$ \\
\hline \multirow[t]{2}{*}{ Understanding reality } & Gender dynamic of major and field & $\begin{array}{l}\text { Participants understand they are in a male-dominated field and will have to set } \\
\text { themselves apart to succeed. }\end{array}$ \\
\hline & Workplace dynamics & $\begin{array}{l}\text { Participants understand that workplace dynamics are gendered and may require } \\
\text { them to do more than their share of work. }\end{array}$ \\
\hline \multirow[t]{2}{*}{ Networking } & Traditional networking & $\begin{array}{l}\text { Participants took advantage of networking opportunities when available, } \\
\text { including alumni connections, guest speakers, and bosses. }\end{array}$ \\
\hline & Women-in-sport-management club & $\begin{array}{l}\text { Participants believed a club could facilitate and improve support for female } \\
\text { students in the major. }\end{array}$ \\
\hline
\end{tabular}


girl that you don't know, like. 'Oh, let me go sit next to the only other girl in the class.' It's so hard to put yourself out there, I guess." Kara added to this sentiment: "But it's funny, when you're the only two that don't know each other. You're best friends instantly." Cindy described it as follows: "There are boys that are really smart and they have a good work ethic. I don't mind being in a group with them." They recognized the gendered nature of the major and understood how to support each other, as well as figure out which male classmates could help them.

In addition, the women experienced personal growth over their time in the major. The participants talked about becoming more comfortable, participating fully in the classroom and interacting with faculty and classmates despite being in the minority. Brooke said,

I feel like, at first, I'm definitely more timid in the major. In my Foundations [of Sport Management] class, one of the professors was like, "You gotta [sic] participate more." Now I have the courage in class to not care what anyone else thinks. Just participate, answer the questions.

Sarah added to this notion:

I agree with Brooke that I did not talk. I took videography as my first sport management class ever, and I was petrified because I was, literally, the only girl. I didn't speak two words. Then, Foundations, and I talked a little bit more. I made some connections with the guys in the class, which helped. I'm still friends with some of them up til [sic] now.

This growing comfort with interacting in the classroom and learning how to work with their male peers helped them not only succeed in the classroom but should help them speak up for themselves in a male-dominated workforce. The students in this study, like those in Harris et al.'s (2015) research, understood the gender discrepancy in the major and in the field as a whole. The participants also found ways to cope with this and persevere in a way that would set themselves up to be successful in their future careers. This included taking on leadership roles in group work, similar to what was discussed in Harris et al.'s (2014) study, and also being comfortable speaking up in class and sharing their opinions, even when they differed from those of their male classmates.

Joining the Conversation. Several of the participants discussed the challenges of participating in conversations with male peers outside of the classroom. The participants stated that male peers often talked about the scores of recent games and various statistics. Female student participants were less interested and knowledgeable about these topics. Women in the focus group believed there was more to working in sport than knowing the statistics and scores in the big four men's sports leagues. Anna showed how she handled this expectation of knowledge in describing an event from her freshman year:

Some guy said something about the Raptors and I said, "What is that?" And they're like, "That's an NBA team. How are you expecting to be Sport Management major if you don't know what that is?" And I said, "Do you know anything about MLS?" And they're like, "No." I said, "Why are you here?" Just something like that.

While Anna had a quick retort to another student who expected her to know about a sport she did not follow, many of the women in our study used other tools to ensure they could join in daily conversations with their male peers. The participants reported using apps on their phones, including ESPN and Bleacher Report. Mary stated, "I always scroll through it [ESPN App] in the morning, right before I go to class." Melissa noted she used these apps to "literally fake it 'til you make it." Similarly, many of their male peers played and talked about fantasy football. In order to join the conversation, Danielle said, "I have an account, but I don't really stay on top of it, but whenever they talk about it, I'm like, 'Yeah, I have an account.' Like, I never play."

Harris et al. (2014) talked about female sport management students developing a coping mechanism for the gender discrepancy in sport management. Enhancing sport knowledge was one of the mechanisms mentioned. The students in this study enhanced their sport knowledge in order to join in the conversations using sports news apps so they gained knowledge of the day's headlines before going to class. This need to stay in "the know" was not surprising, as previous research has suggested keeping up with statistics and scores was one of the primary drivers of mobile app utilization (Vooris, Smith, \& Obeng, 2015). Using mobile apps allowed participants to "fake it" well enough to participate in conversations with their classmates.

Using Minority Status as an Advantage. Another strategy the participants discussed as helpful in overcoming barriers was using their minority status as an advantage. While the students did not verbally self-identify as a minority, their responses indicated that they experienced the major as a minoritized student. Brooke stated, summarizing one group's sentiment on their position within the major, "I think it's almost easier because there's so few females in the major, so it's easier to put yourself out there. Make a statement."

Some of the students also discussed how they perceived that women get called on more frequently in class. There was a mix of reasons why the participants thought this happened, including the women being better students, the women sitting near the front of the classroom, and the professor wanting "the female perception." While professors' wanting the female perception was mentioned as a reason for the women getting called on more frequently, several participants noted that they felt this was rarely the intent of the professors, and some professors went out of their way to not explicitly solicit the female perception. The most commonly discussed reason was that professors were more likely to know women's names. Sarah expanded on this by saying, "I think the name thing is important because it's easier to remember one girl's name than 30 guys' names. That might be the one name in their head, so they're gonna keep calling on you." The participants believed that being the minority, in some ways, helped them in the classroom. Brooke also talked about how it can be an advantage in getting internships:

I feel like sometimes it's almost an advantage to be a female because you do stand out. Right now, I'm shadowing to be an event manager for [athletics event director], and she wants a girl. She wants to have one girl in her event managers. Sometimes it's almost an advantage.

Considering the small percentage of female students, this gives them an advantage in applying to these resume-building positions.

Harris et al. (2014) discussed three coping mechanisms for female students: leadership, enhancing sport knowledge, and working with faculty mentors. Participants' willingness to take advantage of additional opportunities that were open to them because of their minority status in the major could be viewed as an additional coping mechanism. The participant's perception that 
they were called on more than their male peers contradicts Hall and Sandler's (1982) chilly climate finding that male students were called on more and were asked more open-ended questions. This could be due to the perceived minority advantage that the women in this study mentioned - that faculty were able to learn their names more quickly and could thus call on them more easily. The participants believed that being in the minority could benefit them in some ways, particularly with those who already were excelling in the classroom.

Going Above and Beyond. The final tool used to overcome barriers was to go "above and beyond," meaning to be exceptional in their work habits. The students recognized that the major and the field were male dominated. The women in this study understood that to overcome this barrier, they often needed to work harder than their male peers. The participants discussed that they needed to be the best at everything they did, and while they did not always love the extra work involved, they knew it would make them better prepared for the future. Group work was an area where many of the participants talked about doing extra work to make sure the project was done right. Kara mentioned, "Sometimes, I just volunteer myself to do it because I'm afraid they're going to mess it up." The women also talked about getting as much experience as possible so that they could set themselves by being overqualified. Mary said,

I just found myself getting a lot of experience on my own. Because I know I just have to set myself apart, because there are so many men, so I've just been trying to build my resume as much as I can.

This tool of going above and beyond mirrored Harris et al.'s (2014) coping mechanism of taking leadership positions in group work situations. Students in both studies understood the need to take on leadership roles to set themselves apart in the maledominated sport management environment.

While the participants in this study perceived few barriers that would prevent them from succeeding as sport management majors, they discussed many tools that they utilized to overcome the obstacles that do stand in their way. Many of these tools echoed the coping mechanisms discussed by Harris et al. (2014). These women took on leadership roles in group work, used sports news apps to enhance their sport knowledge, and took advantage of their minority status to get to know their faculty better and gain leadership positions and internships. The participants utilized all these coping mechanisms in order to help overcome the reality of being a minority in the sport management major.

\section{Understanding Reality}

The participants demonstrated a clear understanding of the reality of the field of sport management. The women in this study understood that the major and the field are highly gendered. They also appeared to understand the implications of what this meant for them. Two subthemes came from their understanding of the gendered reality of the field: a general understanding of the gender dynamics of the major and field, and that understanding workplace dynamics would be important.

Gender Dynamic of the Major and Field. The women were aware, at least to some extent, of how gendered the major and field were before they even got on campus. Mary stated, "I came in thinking, 'Oh there aren't going to be a lot of girls. There may be a few.' But coming to my orientation, I was like, oh. I was the only one there."
Several other participants echoed this, stating they had similar orientation experiences. Some discussed how others around them challenged their decision to go into sport management because they were women. Brooke recounted,

Before I came to the major, people at home were like, "Oh, you're gonna [sic] be a Sport Management major? You don't know anything about sports." I'm like, "I don't really watch sports that much, but it's sports business." It's totally different from what everyone thinks they are gonna be here.

This idea that if a person did not know enough about sports or watch enough sports, they would not make a good sport management major could contribute to a feeling of a chilly climate in the department for female students (Hall \& Sandler, 1982; Sandler, 2005), particularly when the idea that being a woman automatically equates to a lack of sport knowledge (Harris et al., 2015). However, Brooke displayed an understanding that being in sport management was not just about being a fan or knowing a lot about current events. Rather, it was the business side of sport, and an individual can be successful on the business side of sport without being an avid fan. Kacey mentioned how the classroom is also similar to the gender breakdown in the field, particularly in coaching:

I think I knew too coming in that it was a little unequal here, I guess. I came from more of an exercise science, coaching background, and especially in the coaching industry, even though I coach a sport that's male and female there's still a lot of male coaches, even for the female teams. So, I think that was kind of my first, I guess, introduction to how different it was. I know the same with the classes just a few females.

The women had a clear understanding that they were in a highly gendered major and that this dynamic would not change when they entered the workforce. While the participants experienced some aspects of the chilly climate, they knew it would not change when they entered the workforce. The women in this study also understood that the gender discrepancy meant they had to act differently than their male peers to be successful.

Workplace Dynamics. The women in this study understood that since sport management was a highly gendered field, they needed to create opportunities and support systems for themselves. The participants did this through a strong work ethic, creating support systems, personal growth over time, and strong leadership. Many of the women talked about how they believed they had a strong work ethic and often took on large portions of group work, both out of choice and necessity. Alisha described her work attitude as "I'm just trying to get through it just like everybody else, so just determined, what I've always grew up on I've just had to work like everybody else."

A repeated topic of discussion in the focus groups was around group work. The women discussed how they often did more than their share of group work, sometimes because it was expected as the lone woman in the group and sometimes out of choice because they wanted the work to be up to their standard of excellence. Cindy said,

I feel like I end up usually, I also have trouble delegating work, so I feel like I usually have trouble doing that, plus I feel like they're like, "Oh, you can do it." I'm like, "OK, I guess." That's only when I'm the only girl in the group, which is a decent amount of time. 
While the women were often frustrated by having to carry the weight of group work, they also understood that, in the long run, this extra work would benefit them. Sarah explained how the extra work could help them down the road:

It stinks to be the only girl and have all that work put on you, but then, once you do it, you're the one with the experience. So, they can say, "Yeah, I got a 90 on that paper." But they didn't do it, so now, two years down the line, they're gonna have to do that paper by themselves, and they don't know how because we did it for them. I'm getting the experience and they're not. Stinks for them.

While Sandler (2005) discussed that, in a chilly climate setting, male students may not trust female students to have the ability to complete complex tasks in group work settings, the opposite was found in this study. The women saw their work ethic as better than that of their male peers and would often take on large portions of group projects. In addition, the male students often expected their female group members to take on the more complex aspects of projects, showing that they trusted the female students' academic abilities. The women in this study understood that while they may be doing extra work currently, particularly in a group project, this would pay off when they got jobs and they would be the ones who understood the material they learned. The women would be the ones, not their group members, who knew how to put together a marketing or event plan because they were the ones who did the bulk of the work on the project in school.

The participants also learned that leadership skills are an important part of any group dynamic. Dawn discussed how, in group discussions, she ensured that her voice was heard and took the lead to ensure that the discussions stayed fact based and were not overly biased.

I'm the type of the person where I want to value everyone's opinion, but if I think it's going to go in a direction that is a little unfounded or very opinionated, then I kind of . . . like to speak up and at least try to present some facts to help have a better dialogue about something, if I think it's going a little too opinionated and maybe a little too male-centered then I feel lend my voice and I do often have to.

Gladys summed up the need to make things happen for oneself through working hard and taking leadership in group dynamics when she said, "I feel like we kind of just need to get used to it too because, when we enter into the field, it's mostly going to be males. We might have to do all the work anyway."

The women in this study had a firm understanding of the reality of sport management. The participants understood the gendered reality of the field and understood that they needed to make things happen for themselves if they were going to succeed in the male-dominated field (Harris et al., 2015). The women in this study did this through their work ethic, understanding group dynamics, and taking leadership roles.

\section{Networking}

The women frequently discussed the importance of networking as part of their success in the major and in their future careers. To them, networking took on several forms, including traditional networking with other people who work in sport management. While networking helped some participants overcome barriers and was an aspect of living the reality of the gendered nature of sport management, it was also a significant, reoccurring facet of the discussion that took multiple forms. These different forms of networking made up the two subthemes: traditional networking and a desire for a women-in-sport-management club.

Traditional Networking. The women who participated in this study understood the need for networking to be successful in sport management and took advantage of opportunities available for them to expand their networks. The participants discussed the need to network with professionals in the field in order to set themselves up to succeed in the field. Gladys described her tactic: "I try to talk to as many people as I can because networking here is really important. You never know .... You want to be a sports agent, I'm probably going to get your contact information." Dawn reinforced this idea as well: "My strategy is definitely to network and put myself in positions where, whether I' $m$ in a male-dominated space or female-dominated space, just to put myself in that environment and hopefully succeed."

Many of the women also discussed the usefulness of finding mentors, sometimes through their networking opportunities. Mentors were very important to them. Some of them already had close mentor relationships, and others wanted to seek out mentor relationships. On the topic of mentors, Kacey said,

I think finding mentors and things like that, just people that are looking out for you and trying to help you out and they've been through this or they've done this before, other grad assistants or other people in the program and then as well as the coaches and the staff that I work within the athletics department.

While Kacey found a lot of her connections in her current athletic department, other women talked about how guest speakers and alumni connections often served as great avenues to network and find mentors. Claire said,

I reached out to [female alumna] and she's definitely helped me a lot, just with advice, and I shadowed her a couple times over winter break, so I think having someone in the field, who's also an alumni would really help.

Several of the participants focused on the importance of female-centric networking. Some, like Claire, talked about it in terms of alumni and finding female mentors, while for others, it included networking with other female classmates in order to succeed in the classroom. Sarah said,

With those small groups of girls that are in your class, I know we become really close because we went on a study abroad together. Some of my other friends I've met and become really close with just in my classes. It's easier to make a connection and have someone to work with because you're the only two, so you form a bond.

Many of the other participants agreed with this sentiment. By getting to know the other female students, they had a way to immediately have friends in the class and have somebody to work with.

Harris et al. (2014) discussed finding faculty mentors as an important coping mechanism for female students. The students in this study saw it more broadly. Networking and finding mentorships were seen by the women in the current study as important ways to prepare themselves for their future careers. The participants endeavored to take every opportunity available to them to make connections with those who might help them in the future. The women in this study utilized not only professors, but also alumni, 
coworkers, bosses, and anyone else working in their desired field whom they met along the way to network with and possibly start a mentoring relationship with. The women understood that they had to work harder to overcome the gender discrepancy in the major and future careers (Harris et al., 2015), and one tool to overcome the discrepancy was being very conscious of their networking efforts.

Women-in-Sport-Management Club. The importance of networking prompted the students to mention an initiative they felt would be of benefit to them: a women-in-sport-management club. Gladys said, "I feel like talks like these help a lot. I kind of wish it was a club like Women in Sports, so we could discuss stuff like that." The women articulated different ideas of the purpose of such a club. Some, like Sarah, did not even think it needed to be a formal club, but a social at the beginning of each semester so that the female students could simply get to know each other. Melissa expanded on this by saying, "It would be cool if that did happen; then there is a familiar face walking into your class. Okay, she was there, she seems nice. If not, you're walking in with nothing with everybody else."

While some students just wanted a beginning of the semester meet and greet, others wanted more structure. The participants who wanted more structure than a female student meet and greet suggested bringing in women who worked in sport management to speak to the students about their experiences. Dawn, who attended a formal women-focused conference, said, "I like the idea of the attending a conference or a panel or I like the idea of having it be informal." Kacey gave an example of a conference set up that allowed for this dialogue and networking to occur:

I know I've been to a [Athletic Conference] women's leadership conference for two years in a row for coaching, and the athletic directors are there and coaches are there; and we get to kinda all chat in a more casual setting, and it kinda makes you feel like you have a better connection rather than oh someone came in and lectured to my class about things I've heard a hundred times.

The women in this study all supported the idea of having a womenin-sport-management club.

The participants saw networking as an important part of preparing for their careers in sport management. It helped them ensure that they had connections with professionals when they entered the job market. The participants explicitly asked for more help networking with other female students and women in the industry through the creation of a women-in-sport-management club or mentorship initiative. This request was supported by previous research on mentoring and the benefits of same-sex mentoring relationships. Avery, Tonidandel, and Phillips (2008) found that in coaching, same-sex mentor pairings led to more career development and psychosocial development for the protégé than in sex-dissimilar pairing. In addition, Morris, Arthur-Banning, and McDowell (2014) found that female assistant coaches believed that same-sex mentorship and women-specific networking events were important strategies to overcoming the constraints they faced to becoming head coaches. By providing women-specific mentorship or networking opportunities, the female sport management majors would be able to take advantage of the strong-tie, womenspecific relationships that have been found to be beneficial to women in coaching, a similarly sex-segregated field (Avery et al., 2008; Morris et al., 2014). The women had clearly put thought into what they needed to do to succeed in the sport management field. Knowing that the field was highly gendered and often stacked against them, the students understood the need for networking and working hard to be the best students and potential employees they could be.

\section{Implications}

The results of this study led to several implications for sport management programs and faculty. The participants understood the reality of the male-dominated major and field. Due to this, they often went above and beyond in the classroom and work in order to be prepared to succeed in the field. This often meant they sought mentorship and networking whenever possible, with fellow classmates, their faculty, and sport management professionals. Faculty should work to ensure these female students have the opportunity to make these connections, particularly with other women who can act as role models and mentors.

The women in this study highly valued their ability to connect with their female peers and with women working in this field. Therefore, women-in-sport-management clubs and peer mentorship programs would be beneficial to retaining female students by allowing them to meet and network with each other outside of the classroom setting. These clubs could also bring in guest speakers from the field who can speak to the students about succeeding in sport management. On this point of female guest speakers, when faculty utilize guest speakers, they should consider the gender of their speakers. By regularly bringing in a balance of male and female guest speakers, female students are able to see other women who are successful in the field and who can serve potentially as networks, mentors, or role models.

Another implication for the classroom concerns that of classroom conduct and group dynamics. The women in this study spoke of being called on more frequently than some of their male peers. Professors should ensure that they are not simply calling on women to hear the female perspective, as that unfairly singles out students, and one person can never speak for an entire demographic. In addition, the participants stated that they often carried the weight of their group members. While the students would prefer to make their own groups to help avoid this, the authors recognize that, for various reasons, faculty may not want to do this. In this case, faculty should have checked in to ensure that in group work settings, all members were carrying their weight.

\section{Limitations and Future Research}

One limitation of this research is that it was limited to women who were currently enrolled as sport management majors. We did not interview those who transferred to a different major. To fully understand the picture of how women experience the major, those who have chosen to leave the major could provide valuable data about why they chose to leave. If those who have chosen to leave the major experienced the chilly climate more acutely or were less successful in coping with the challenges of being in the minority, we could get more information on how to improve our retention of women in the major. Future research should consider both current majors and those who have chosen to change majors from sport management.

Future research should also consider the experiences of male students to determine if their perceptions and strategies to succeed in a competitive field are similar to those of women. Because of the exploratory nature of this study, another limitation was that it only addressed the experiences of one institution. Future research should 
address the experiences of female students at other schools of varying sizes and locations. A final limitation was the low number of graduate students in the study. Future research with a greater number of graduate students would allow researchers to understand if there were differences in the experiences between undergraduate and graduate students.

\section{Conclusion}

This study found that female sport management majors had a clear understanding of their position as a minority in the major and in the profession of sport management. These women commonly implemented coping mechanisms, which included networking, utilizing apps in order to join conversations, and attempting to distinguish themselves through their work ethic. Some elements of the chilly climate, such as women being made to feel as if they did not have enough sports knowledge, were found among the participants, while other elements, such as instructors not calling on them as frequently in the classroom, were not supported. This may suggest that some progress is being made when it comes to inclusion within the major of sport management. It may also indicate that modern women have a stronger understanding of the gender dynamic of the field and actively seek out coping mechanisms to overcome or deal with the chilly climate. While they did not always enjoy having to put in extra work compared with their male peers, especially when it came to group work, they expressed that this extra work would help them be more prepared for their future careers.

In addition, the participants valued the networks they were making with their female classmates and women in the field. The women in this study wanted more opportunities to network with their female peers as well as to hear from women in the sport business field. They desired a formalized, women-in-sport-management organization or mentorship program to help support them. Overall, the female participants in this study showed a remarkably clear grasp of how to succeed in sport management and, rather than being discouraged by their minority status, appeared ready to tackle the challenges ahead of them. While elements of the chilly climate persist in many corners of higher education, there may be evidence of a thaw in the field of sport management.

\section{References}

Acosta, R.V., \& Carpenter, L.J. (2014). Women in intercollegiate sport: A longitudinal, national study. Thirty-seven year update, 1977-2014. Retrieved from http://www.acostacarpenter.org/

Avery, D.R., Tonidandel, S., \& Phillips, M.G. (2008). Similarity on sports sidelines: How mentor-protégé sex similarity affects mentoring. Sex Roles, 58, 72-80. doi:10.1007/s11199-007-9321-2

Ball, J.A. (2012). The gender gap in undergraduate business programs in the United States. Journal of Education for Business, 87, 260-265. doi:10.1080/08832323.2011.617792

Barnhill, C.R., Czekanski, W.A., \& Pfleegor, A.G. (2018). Getting to know our students: A snapshot of sport management students' demographics and career expectations in the United States. Sport Management Education Journal, 12, 1-14. doi:10.1123/smej.2015-0030

Bettinger, E.P., \& Long, B.T. (2005). Do faculty serve as role models? The impact of instructor gender on female students. The American Economic Review, 95, 152-157. doi:10.1257/000282805774670149

Boyer, E.L. (1987). College: The undergraduate experience in America. New York, NY: Harper \& Row.
Chen, S., Adams-Blair, H., \& Miller, A. (2013). Professional expectations of sport management students as related to academic curricular alignment support and preparation. Universal Journal of Management, 1, 132-137.

Creswell, J.W., \& Creswell, J.D. (2018). Research design: Qualitative, quantitative, and mixed methods approaches (5th ed.). Thousand Oaks, CA: Sage.

Glaser, B.B., \& Strauss, A.L. (1967). The discovery of grounded theory: Strategies for qualitative research. Chicago, IL: Aldine Publishing Company.

Hall, R.M., \& Sandler, B.R. (1982). The classroom climate: A chilly one for women? Washington, DC: Association of American Colleges.

Hambrick, M.E., Simmons, J.M., \& Mahoney, T.Q. (2013). An inquiry into the perceptions of leisure-work-family conflict among female Ironman participants. International Journal of Sport Management and Marketing, 13, 173-199. doi:10.1504/IJSMM.2013.059719

Hancock, M.G., \& Greenwell, C.T. (2013). The selection of a sport management major: Factors influencing student choice from a consumer-oriented perspective. Sport Management Education Journal, 7, 13-24. doi:10.1123/smej.7.1.13

Harding, S. (1987). Feminism \& methodology. Bloomington, IL: Indiana University Press.

Harris, F.K., Grappendorf, H., Aicher, T., \& Veraldo, C. (2015). "Discrimination? Low pay? Long hours? I am still excited": Female sport management students' perceptions of barriers toward a future career in sport. Advancing Women in Leadership, 35, 12-21.

Harris, F.K., Grappendorf, H., Veraldo, C., \& Aicher, T. (2014). A concern for the future of sport management: Female students' perceptions toward their sport management degree. Global Sport Business Journal, 2, 28-43.

Hartsock, N. (1983). The feminist standpoint: Developing the ground for a specifically feminist historical materialism. In S. Harding \& M.B. Hintikka (Eds.), Discovering reality (pp. 283-310). Dordrecht, The Netherlands: Springer.

Hums, M.A. (1994). Successful recruitment and retention of minority students in sport management. Paper presented at the North American Society of Sport Management Conference, Pittsburgh, PA.

Jones, D.F., Brooks, D.D., \& Mak, J.Y. (2008). Examining sport management programs in the United States. Sport Management Review, 11, 77-91. doi:10.1016/S1441-3523(08)70104-9

Krueger, R.A., \& Casey, M.A. (2000). Focus groups: A practical guide for applied research. Thousand Oaks, CA: Sage.

Lapchick, R. (2017). The 2018 racial and gender report card: National Football Association. Orlando, FL: Institute for Diversity and Ethics in Sport. Retrieved from http://nebula.wsimg.com/ 1a7f83c14af6a516176740244d8afc46?AccessKeyId=DAC3A56D8 FB782449D2A\&disposition=0\&alloworigin $=1$

Lapchick, R. (2018a). The 2018 racial and gender report card: Major League Baseball. Orlando, FL: Institute for Diversity and Ethics in Sport. Retrieved from http://nebula.wsimg.com/2b20e1bb7ea 3 fad9f45263b846342d04?AccessKeyId=DAC3A56D8FB782449D 2 A\& disposition $=0 \&$ alloworigin $=1$

Lapchick, R. (2018b). The 2018 racial and gender report card: National Basketball Association. Orlando, FL: Institute for Diversity and Ethics in Sport. Retrieved from http://nebula.wsimg.com/ b10c21a67a6d1035091c4e5784c012f4?AccessKeyId=DAC3A56D8 FB782449D2A\&disposition=0\&alloworigin $=1$

Leberman, S., \& Shaw, S. (2015). 'Let's be honest most people in the sporting industry are still males': The importance of socio-cultural context for female graduates. Journal of Vocational Education \& Training, 67, 349-366. doi:10.1080/13636820.2015.1057212 
Levsen, V.B., Goettel, N., Chong, F., \& Farris, R. (2001). Do we practice diversity in business schools? International Journal of Educational Management, 15, 167-171.

Marcus, J. (2017, August 8). Why men are the new college minority. The Atlantic. Retrieved from https://www.theatlantic.com/education/ archive/2017/08/why-men-are-the-new-college-minority/536103/

Moore, M.E. (2008). Gender openness in managerial education: A sport management focus. Gender in Management, 23, 355-370. doi:10. $1108 / 17542410810887374$

Moore, M.E., \& Huberty, L. (2014). Gender differences in a growing industry: A case study of sport management education. International Journal of Humanities and Social Science Invention, 3, 19-25.

Morris, E., Arthur-Banning, S., \& McDowell, J. (2014). Career strategies of millennial generation female assistant coaches. Journal of Intercollegiate Sport, 7, 175-197. doi:10.1123/jis.2013-0041

Munday, J. (2014). The practice of feminist focus group. In S.N. Hesse Biber (Ed.), Feminist research practice: A primer (pp. 233-263). Thousand Oaks, CA: Sage.

National Center for Education Statistics. (2017). Fast facts. Retrieved from https://nces.ed.gov/fastfacts/display.asp?id=372

Pascarella, E.T., Whitt, E.J., Edison, M.I., Nora, A., Hagedorn, L.S., Yeager, P.M., \& Terenzini, P.T. (1997). Women's perceptions of a "chilly climate" and their cognitive outcomes during the first year of college. Journal of College Student Development, 38, 109-124.

Patton, M.Q. (2002). Qualitative research and evaluation methods (3rd ed.). Thousand Oaks, CA: Sage Publications.

Sandler, B.R. (2005). The chilly climate. Washington, DC: National Association for Women in Education. Retrieved from https://sun. iwu.edu/ mgardner/Articles/chillyclimate.pdf
Sauder, M.H., Mudrick, M., \& DeLuca, J.R. (2018). Perceived barriers and sources of support for undergraduate female students' persistence in the sport management major. Sport Management Education Journal, 12(2), 69-79. doi:10.1123/smej.2017-0025

Taylor, E.A., Johnson, A., Hardin, R., \& Dzikus, L. (2018). Kinesiology students' perceptions of ambivalent sexism. NASPA Journal About Women in Higher Education, 11(3), 233-246. doi:10.1080/ 19407882.2017.1423080

Taylor, E.A., Smith, A.B., Rode, C.R., \& Hardin, R. (2017). Women don't know anything about sports: Contrapower harassment in the sport management classroom. Sport Management Education Journal, 11, 61-71. doi:10.1123/smej.2016-0013

Thomas, D.R. (2006). A general inductive approach for analyzing qualitative evaluation data. American Journal of Evaluation, 27(2), 237-246. doi:10.1177/1098214005283748

U.S. Department of Labor. (2017). Woman in the labor force. Retrieved from https://www.dol.gov/wb/stats/NEWSTATS/facts/women_lf.htm\#one

Vooris, R., Smith, C.M.L., \& Obeng, C. (2015). Reflections of two-screen users: How people use information technology while watching sports. International Public Health Journal, 7, 383-389.

Whitmarsh, L., Brown, D., Cooper, J., Hawkins-Rodgers, Y., \& Wentworth, D.K. (2007). Choices and challenges: A qualitative exploration of professional women's career patterns. The Career Development Quarterly, 55, 225-236. doi:10.1002/j.2161-0045. 2007.tb00079.x

Yiamouyiannis, A., \& Osborne, B. (2012). Addressing gender inequities in collegiate sport: Examining female leadership representation within NCAA sport governance. SAGE Open, 2(2). doi:10.1177/ 2158244012449340 